
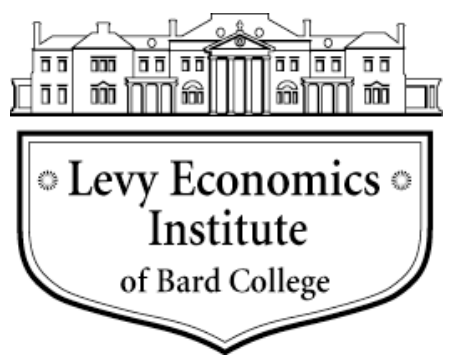

Working Paper No. 719

\title{
Reorienting Fiscal Policy after the Great Recession
}

\author{
by \\ Pavlina R. Tcherneva \\ Levy Economics Institute of Bard College
}

May 2012

The Levy Economics Institute Working Paper Collection presents research in progress by Levy Institute scholars and conference participants. The purpose of the series is to disseminate ideas to and elicit comments from academics and professionals.

Levy Economics Institute of Bard College, founded in 1986, is a nonprofit, nonpartisan, independently funded research organization devoted to public service. Through scholarship and economic research it generates viable, effective public policy responses to important economic problems that profoundly affect the quality of life in the United States and abroad.

Levy Economics Institute P.O. Box 5000

Annandale-on-Hudson, NY 12504-5000

http://www.levyinstitute.org

Copyright (C) Levy Economics Institute 2012 All rights reserved 


\begin{abstract}
The paper evaluates the fiscal policy initiatives during the Great Recession in the United States. It argues that, although the nonconventional fiscal policies targeted at the financial sector dwarfed the conventional countercyclical stabilization efforts directed toward the real sector, the relatively disappointing impact on employment was a result of misdirected funding priorities combined with an exclusive and ill-advised focus on the output gap rather than on the employment gap. The paper argues further that conventional pump-priming policies are incapable of closing this employment gap. In order to tackle the formidable labor market challenges observed in the United States over the last few decades, policy could benefit from a fundamental reorientation away from trickle-down Keynesianism and toward what is termed here a "bottom-up approach" to fiscal policy. This approach also reconsiders the nature of countercyclical government stabilizers.
\end{abstract}

Keywords: Fiscal Policy; American Recovery and Reinvestment Act of 2009; Trickle-Down Keynesianism; Countercyclical Employment Policy

JEL Classifications: E24, E25, E61, E62, E65, H1, H5, J2, J6, J48 


\section{INTRODUCTION}

In the contemporary policy making environment, the borders of what is considered to be possible outline an increasingly narrow terrain. This is particularly true with respect to fiscal policy, where the choices seem to be limited - at best - to two options, one of them disastrous and the other woefully inadequate. Austerity (attempting to achieve expansion through fiscal contraction) and conventional aggregate demand management (enlarging government deficits in an attempt to "prime the pump" of economic growth) mark the boundaries within which fiscal policy is allowed to roam. The results of this limited policy space have been unenviable. While austerity (shrinking incomes and spending when demand is already collapsing), as the European experience demonstrates, is decidedly the wrong approach to stabilization, pump-priming works toward restoring demand, but fails to deliver long-run stability, genuine full employment, and better income distribution.

In the case of the US, the relatively disappointing results from the stimulus packages to address the Great Recession are being used to legitimize an increasingly popular view of the "new normal," namely that Keynesianism has once again been "proven" to be ineffective, ${ }^{1}$ that the "natural" rate of unemployment is now much higher than conventional estimates (Weidner and Williams 2011; Daly et al. 2011), and that the rise of income inequality is beyond policy control. In other words, conventional wisdom now holds that the inadequate success of fiscal intervention over the last few years has demonstrated that there is very little that policy can do to deliver shared economic prosperity over the short or long run. It is this view of the "new normal" that has also fueled increasing support for austerity policies, where the foremost objective of government is believed to be a reduction of federal deficits and debt (Reinhart and Rogoff 2009).

The argument presented here is that fiscal policy, as it is conventionally practiced, is indeed lacking, but the conclusions are precisely the opposite of the conventional view. Government policy can deal effectively with unemployment, income distribution, and instability over the long run, so long as the fiscal policy is reoriented away from its contemporary trickledown Keynesian orientations, toward what can be called a "bottom up" approach to macroeconomic stabilization. What is required is a novel way of thinking about fiscal policyone that eschews austerity, moves beyond the limits of conventional pump-priming, and rethinks

\footnotetext{
${ }^{1}$ Recall the declarations of the 1980s that Keynesianism was dead (Lucas 1980).
} 
the nature of the government countercyclical stabilizers. To do so, this paper will examine fiscal policy actions in the US since 2008 to examine the shortcomings of the conventional approach and offer new ways of thinking about public policy.

\section{FISCAL POLICY DURING THE GREAT RECESSION}

\section{What Is Fiscal Policy Proper?}

A foundational question is what precisely constitutes fiscal policy. Traditionally, the focus has been on spending and taxation by the federal government and, specifically, on purchases of real goods and services that affect growth — namely the government component of gross domestic product. But fiscal policy includes measures that affect overall macroeconomic conditions and is, therefore, much broader than the government purchases included in the GDP. Government spending on transfer payments such as unemployment insurance (UI), temporary assistance for needy families (TANF), social security, Medicare, tax credits, direct subsidies, contracts to firms, and many others are often analyzed as part of fiscal policy because they impact income, employment, poverty, investment, and growth. What is normally not included in the analysis of fiscal policy are government transfer payments and other assistance to financial institutions, which in the latest crisis constituted a large component of government spending that dwarfed the conventional expenditures. Programs like the Troubled Asset Relief Programs of 2008 (TARP I) and the Financial Stability Plan of 2009 (dubbed TARP II), which are normally thought of as monetary policy, in fact constitute fiscal policy proper. This is because just like UI, TANF, or any program that is funded for example through the departments of education, defense, transportation, etc., they too require an act of Congress and a specific budget (in this case to finance the purchases of toxic financial assets from financial institutions). ${ }^{2}$ These two programs were executed by the Federal Reserve in coordination with the Treasury, but they provide direct subsidies to financial institutions that have been authorized by the federal government for the purchases of non-performing financial assets. There are a number of other Federal Reserve functions that are also discussed in the literature as monetary policy, whereas they should be properly treated as fiscal policy; these functions are euphemistically called the "fiscal

\footnotetext{
${ }^{2}$ The Federal Reserve has a very limited authority under Section 14 of the Federal Reserve Act to purchase financial assets, which include only assets issued or guaranteed by the federal government. Notably absent is the authority to purchase privately issued assets, which is why a Congressional budget and approval of those two programs was required.
} 
components" of monetary policy (Bernanke 2000; for detailed analysis, see Tcherneva 2011a). At the federal level, fiscal policy proper includes tax incentives and rebates, any purchases of real goods, services, or financial assets by government, and the provision of direct subsidies and transfer payment to firms, households, states, and financial institutions. While an examination of the government's subsidies to banks and purchases of toxic financial assets under TARP I and TARP II is beyond the scope of this paper, it is important to get a sense of the magnitude of the expenditures involved relative to those included in the conventional stimulus packages for comparison purposes and proper assessment of government stabilization efforts.

\section{Fiscal Policy Initiatives in Response to the Great Recession}

The economy was already in a recession prior to the September 2008 financial meltdown. The George W. Bush administration quickly passed a stimulus package consisting of $\$ 152$ billion in tax rebates for 2008. The other conventional stimulus package to deal with the crisis was passed by the Obama administration in 2009 , allocating $\$ 787$ billion (which later grew to $\$ 840$ billion) to deal with the fallout from the financial crisis and specifically with the resulting massive unemployment problem. The package known as the American Recovery and Reinvestment Act (or the Recovery Act hereafter) appropriated funds for various purposes that were distributed over the course of four years, averaging about $\$ 210$ billion per year.

At the same time, both the Bush and Obama administrations passed two other unconventional emergency measures to purchase non-performing financial assets from troubled banks. TARP I under Bush allocated $\$ 700$ billion for the recapitalization of insolvent financial institutions, which included direct injection of funds into banks, purchases of mortgage-backed securities and other private debt from bank balance sheets, and the de facto nationalization of the insurance giant AIG. TARP II appropriated up to \$2 trillion dollars in government subsidies for the continued purchases of toxic assets from bank balance sheets, for additional procurement of government-sponsored enterprise (GSE) debt, and for assistance with mortgage refinance. In other words, whereas conventional fiscal stimulus measures targeted to the real economy amounted to a little less than $\$ 1$ trillion (\$152 billion under Bush and $\$ 840$ billion under Obama), unconventional fiscal measures that provided direct assistance to the financial sector through TARP I and TARP II allocated three times that amount - up to \$3 trillion dollars. The focus of policy had largely been on the financial rather than the real sector in hope that this 
assistance would trickle down from Wall Street to Main Street in the form of new credit for consumption and investment. But in an economy with already highly leveraged households and firms, which are experiencing depressed expectations, high unemployment, and collapsing profits and sales, neither lenders nor borrowers were interested in new credit.

In essence, the fiscal approach to economic stabilization was upside-down. What was required was not an increase in credit (i.e., indebtedness) to grease the economy's wheels, but an increase in incomes and employment first. It is not surprising then that the injection of liquidity into the financial sector, which was still plagued by balance sheet problems and in need of major reorganization and reform, has not flowed through the economy to stimulate growth. At the same time, the conventional fiscal measures, which are traditionally aimed at stabilizing employment, incomes, sales, and overall profitability received much smaller funding.

The question then becomes whether the relatively sluggish recovery, dismal employment outcomes, and worsening income inequality are in fact problems of misdirected policy focus, i.e., are they problems of insufficient conventional government spending on the real sector? The following pages will argue that, although there is a lot of merit in this argument, far more important is the manner in which conventional fiscal policy is executed. Indeed the traditional aggregate demand management approach is fundamentally inadequate for dealing with the very important problems that plague labor markets. Priming the pump of economic growth, too, is an upside-down fiscal approach to macroeconomic stabilization. It focuses on the output gap, rather than the employment gap, and to the extent that it improves labor market conditions, it does so for those who are considered employable and experience relatively short spells of unemployment, but is never able to provide similar improvements to the employment conditions for all and especially for the most vulnerable. What is required is a fundamental reorientation of fiscal policy that deals with the unemployment problem in a rigorous manner by delivering robust employment, better income distribution and sustainable growth. Before making this case, let us examine how the conventional pump-priming approach is exemplified in the Recovery Act of 2009, and how it impacted unemployment.

\section{Status Quo Fiscal Policies in the American Recovery and Reinvestment Act of 2009}

Irrespective of their theoretical persuasion, there is broad consensus among economists that the primary objective of fiscal policy is to stimulate investment and growth where improvements in 
the labor market are a byproduct of such policies. Indeed, apart from the anti-growth literature, there is generally no other way of thinking about the role and place of fiscal policy. Whether the preferred policy tools are tax incentives, direct expenditures, subsidies, or other, the key is to close the output gap between current and potential output, leaving reductions in the unemployment rate to develop as a secondary effect. This pro-growth approach is motivated by Okun's Law, which is a hallmark of the Neoclassical Synthesis, though many contemporary mainstream and heterodox economists embrace its logic even as they contest the precise empirical relationship between growth and employment (e.g., Okun 1962; Berglund 2006; Arnold 2009). In terms of practical success, this orientation to fiscal policy has proven to be effective (though decreasingly so) in halting the rise in unemployment, and largely ineffective in rapidly reversing (much less eliminating) joblessness over the short or long run. The first problem with this approach toward fiscal policy is that it fails to recognize the asymmetric nature of demand changes. Whereas unemployment develops quickly as a consequence of sharp reductions in total private spending, a countercyclical injection of expenditures by the public sector of equal amount does not guarantee a return to previous employment levels. This is because once the economy enters a recession and unemployment develops, the impact on expectations and liquidity preference is such that any windfall income that results from increased government spending could be directed towards safe non-employment generating financial assets, rather than being quickly ploughed back into productive investments that have high employment elasticities. Aggregate demand management suffers from other shortcomings, as well (see Tcherneva 2011b), but is nevertheless a crucial policy for establishing a floor to collapsing demand in recessions. The difficulty with conventional fiscal policies is that priming the pump is never sufficiently aggressive to bring the economy anywhere close to full employment and when it is, it tends to be inflationary and erode the income distribution. The fear of inflation, in particular, has legitimized stabilization policies that aim to keep the economy below its full capacity, i.e., in what Keynes termed a "quasi-slump." And though such policies are often called Keynesian, they do not conform to Keynes's own approach to full employment and macroeconomic stabilization (Tcherneva 2012). "The right remedy for the trade cycle," Keynes argued, "is not to be found in abolishing booms and thus keeping us permanently in a quasi-slump; but in abolishing slumps and thus keeping us permanently in a quasi-boom” (Keynes 1964[1936]: 322). This can be accomplished by direct employment and targeted public 
investment in distressed areas and regions, for the purposes of achieving a tight full employment, which for Keynes meant 1 percent unemployment rate (Keynes 1980: 303). By contrast, the status quo's focus on the quasi-slump means that conventional economic wisdom has deemed acceptable a situation in which some measure of unemployment persists. The profession has essentially relabeled as "full employment" the unemployment condition where 5 percent of the workforce wants to work but cannot find employment, e.g., see the Congressional Budget Office's Non-Accelerating Inflation Rate of Unemployment (NAIRU) estimates (CBO 2011a). It is this definition of full employment and this approach to fiscal policy that has guided the stabilization efforts of the current administration.

The Recovery Act of 2009, which initially allocated $\$ 787$ billion over the course of four years, included \$288 billion in tax benefits, \$265 billion in contracts, grants, and loans, and \$234 billion in entitlements (www.recovery.gov). The economic team of president Obama outlined clearly their methodology and approach toward macroeconomic stabilization in the report titled The Job Impact of the American Recovery and Reinvestment Plan (Romer and Bernstein 2009; see also Arnold 2009). The methodology consists of three steps. The first is to specify a prototypical package that outlines the various types of government expenditures. The second is to estimate the effect of these expenditures on GDP, where the economic team uses some conventional estimates for the multiplier effects of government spending and tax rebates on the GDP. And the final step is to estimate the number of jobs created as a result of the growth in GDP (Ibid.: 14). ${ }^{3}$ The program was projected to create or save 3 to 4 million jobs and bring the unemployment rate down to 7 percent by 2010 (and 6 percent by 2012). Note that the unemployment rate in March 2012 stood at 8.2 percent. The growth projections, however, were accurate. Real GDP from 2009 to 2010 grew by 3.7 percent, which is the exact estimate of the Romer-Bernstein report (2009). Yet during the same period (2009-2010), the economy experienced not a job growth of the expected 3 million jobs, but a cumulative loss of payroll employment of over 4 million jobs, after already shedding 3.6 million jobs in 2008 alone. Of course, in the absence of the Recovery Act, the unemployment level would have been much higher, but the unemployment projections nevertheless were off the mark (see Figure 1). Policy

\footnotetext{
${ }^{3}$ The FRB/US macroeconomic model, which explicitly incorporates an Okun law relationship, estimates that an increase of 1 percent of GDP will result in employment of approximately 1 million jobs, or about three-quarters of a percent.
} 
makers assessed poorly the labor market trends that would develop, even though it was already apparent in 2008 that the unemployment problem they would face would be formidable.

Figure 1 Unemployment projections with and without the stimulus and actual unemployment

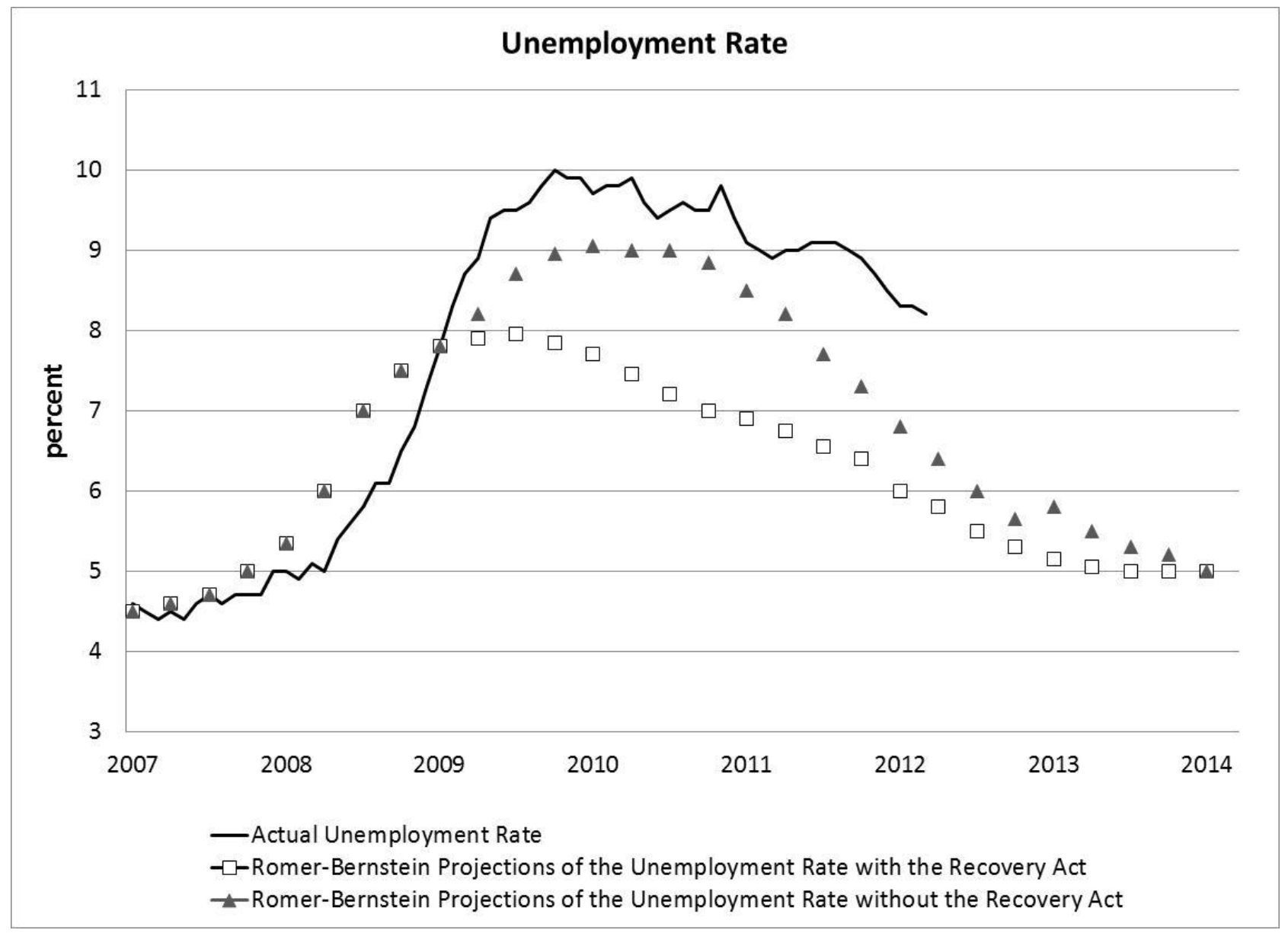

Source: www.bls.gov and Romer and Bernstein (2009)

The difficulty with the government's policy response rested not just in the underestimation of the magnitude of the unemployment problem. The fundamental problem lied in the reliance on the very relationship between growth and unemployment as a useful policy guide. Indeed after a 3.5 percent collapse in real GDP from 2008 to 2009, the economy has been growing steadily at an average annual rate of 2.6 percent in real terms; yet the conditions of the labor markets have been dismal at best. 


\section{THE FUNDAMENTAL PROBLEM: THE UNEMPLOYMENT GAP}

\section{Unemployment and Inequality in the Postwar Era}

Because the focus on the output gap has permanently relegated unemployment to a secondary problem, policy makers do not explicitly target joblessness. This was not always the case. In the immediate postwar era, even after the New Deal WPA projects ended, direct job creation through public works was among the conventional fiscal policy tools. The gradual abandonment of direct public employment programs over subsequent decades, the devolution of federal services to the state level that began in the 1970s, and the preference for tax incentives over direct spending during the last four decades are among the reasons why direct employment schemes became increasingly marginalized. This shift in policy perspective occurred at a time when labor markets became more precarious under the pressures of globalization and supply-side policies. Thus, precisely when public employment and investment were most needed to counteract the erosion in labor market conditions, these policy options were no longer available.

As a result, two main trends were observed. Long-term unemployment became an increasingly large share of total unemployment and income inequality eroded dramatically. The US labor market became less and less agile, unable to generate sufficient number of jobs to absorb the unemployed. Supply-side policies pursued greater labor market flexibility, yet more and more jobless individuals found it difficult to reenter the labor market. As Figure 2 indicates, there has been a secular uptrend in long-term unemployment as a share of total unemployment over the last few decades. Since the 1970s, an increasing proportion of the jobless experienced longer spells of unemployment (peaking at 61 percent of all unemployed in 2010), whereas those who were able to find employment relatively swiftly (within 3-4 months) became a smaller and smaller share of the unemployed (Figure 2). 
Figure 2 Long and short-term unemployment in the US, as \% of all unemployed

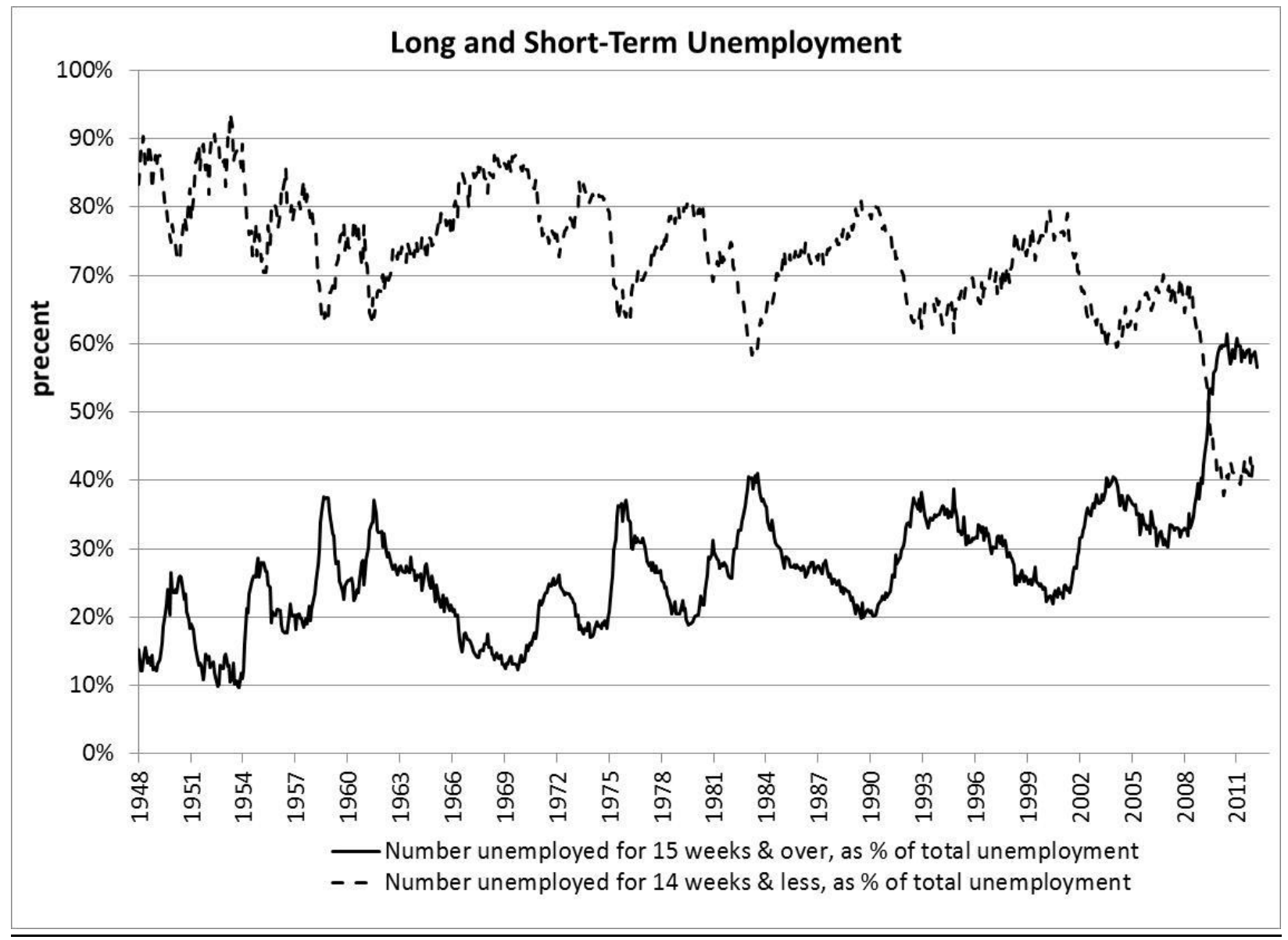

Source: Author's calculations from www.bls.gov data

The income inequality trends were even more dramatic. From 1977 to 2007, real average income in the US grew by $\$ 17,669$, where 90 percent of the gains went to the top 10 percent of the income distribution. During the previous three decades, by contrast (i.e., in the immediate postwar era from 1946 to 1976), average income grew by $\$ 18,673$, where the majority of income growth (70 percent) went to the bottom 90 percent of US households and only 30 percent went to the wealthiest 10 percent. The most rapid increase in income inequality in the recent period was observed during the euphoric first decade of the $21^{\text {st }}$ century, right before the financial crisis. The only other time in history when the US has seen such dramatic erosion in the income distribution was during the roaring 20s. In both periods, the top 10 percent captured all income growth, whereas income for the bottom 90 percent declined.

But there is one fundamental difference between these two periods: whereas the Great Depression witnessed a prolonged collapse in incomes across the board, all of the subsequent 
income growth during the recovery went to the bottom 90 percent. From 1929 to 1947, average income grew by $\$ 5,708$ and all gains in income were captured by the bottom 90 percent. Can we expect with any certainty today that the current recovery will bring a similar trend for the vast majority of US households? This is highly unlikely. Whereas in the immediate aftermath of the 1929 collapse, incomes for all households irrespective of their social location collapsed, the recovery brought shared prosperity and all income gains went to the bottom 90 percent. By contrast, in the two short years of recovery after the Great Recession, income grew quickly and all of the gains were captured by the top 10 percent, the vast majority of which went to the top 0.01 percent (Saez 2012). In other words, the 2008-2010 period has been witness to the largest and swiftest transfer of income to the top in history (Table 1).

Table 1 US Income Inequality

\begin{tabular}{|c|c|c|c|}
\hline & $\begin{array}{c}\text { Average } \\
\text { income growth }\end{array}$ & Top $10 \%$ & Bottom 90\% \\
\hline $\begin{array}{l}\text { The postwar economy } \\
\text { first three postwar decades: 1946-1976 } \\
\text { subsequent three decades: } 1977-2007\end{array}$ & $\begin{array}{l}\$ 18,673 \\
\$ 17,669\end{array}$ & $\begin{array}{l}\text { captured } 30 \% \\
\text { captured } 90 \%\end{array}$ & $\begin{array}{l}\text { captured } 70 \% \\
\text { captured } 10 \%\end{array}$ \\
\hline $\begin{array}{l}\text { Bubble periods } \\
1919-1928 \\
1999-2007\end{array}$ & $\begin{array}{l}\$ 1,428 \\
\$ 3,918\end{array}$ & $\begin{array}{l}\text { captured } 100 \% \\
\text { captured } 100 \%\end{array}$ & $\begin{array}{l}\text { declined } \\
\text { declined }\end{array}$ \\
\hline $\begin{array}{l}\text { Two major financial crises and two years later } \\
1929-1931 \\
2008-2010\end{array}$ & $\begin{array}{c}\text { declined } \\
\text { grew }\end{array}$ & $\begin{array}{c}\text { declined } \\
\text { captured } 100 \%\end{array}$ & $\begin{array}{l}\text { declined } \\
\text { declined }\end{array}$ \\
\hline $\begin{array}{l}\text { Two decades after the Great Crash } \\
\text { 1929-1949 }\end{array}$ & $\$ 5,611$ & declined & captured $100 \%$ \\
\hline
\end{tabular}

Note: Figures in 2008 dollars.

Source: Saez 2012, Economic Policy Institute, and author's calculations

In sum, in the current period, the unemployment gap and income inequality have grown beyond those of any other time in postwar history because they are unraveling on the coattails of the disturbing long-term trends outlined above, which in turn have been enabled by shifts in fiscal policy away from direct public employment and investment and toward trickle-down supply- and demand-side policies (more below). Policy has both failed to recognize these longterm trends and has contributed to their development. Whereas the recent policy response has improved aggregate incomes much faster than that during the Great Depression, it has failed to address the wide range of labor market challenges we face today. To improve policy 
effectiveness, these deeply entrenched problems need to become an explicit target of any fiscal response. This can be accomplished when policy is refocused on closing the employment gap (rather than the output gap), which would bring those problems into view.

\section{The Employment Gap}

The last ten years began reversing the strong gains in the labor force participation rate of the previous decades, culminating in a precipitous decline since the start of the recession in 2007. More telling of the size of the employment gap and the ability of the economy to generate jobs is the employment-to-population ratio, which shows the proportion of working age individuals who are employed - a ratio that has collapsed to a 3-decade low. The two ratios (Figure 3) indicate that the improvements in the unemployment rate over the last few quarters are largely due to the mass exodus of individuals from the labor force, discouraged by the absence of employment opportunities. The Bureau of Labor Statistics (BLS) keeps track of an alternative measure of unemployment (U-6) that includes all discouraged, marginally attached, and other individuals who are working part-time for economic reasons, to get a better measure of the true unemployment rate (Figure 4). Notably, the difference between the official and alternative measures of unemployment has been expanding: throughout most of the data's history that difference hovered between 3 and 4 percent, while since 2009 it has doubled to 7 percent, indicating that the "invisible" unemployment problem to tackle is far greater than in the past (Figure 4). Whereas the official unemployment rate excludes individuals who have not looked for employment for more than four weeks, the broader U-6 measure includes those who have been looking for jobs for up to 12 months. Nevertheless, if we consider that in the US there are anywhere between 2 and 5 million people who have been collecting unemployment insurance for at least two years, the broader measure also likely underestimates the number of discouraged people, who wish to work but cannot find employment (see, for example, Mayer 2010 and Wiedemer 2011). 
Figure 3 Labor force participation rate and employment-to-population ratio

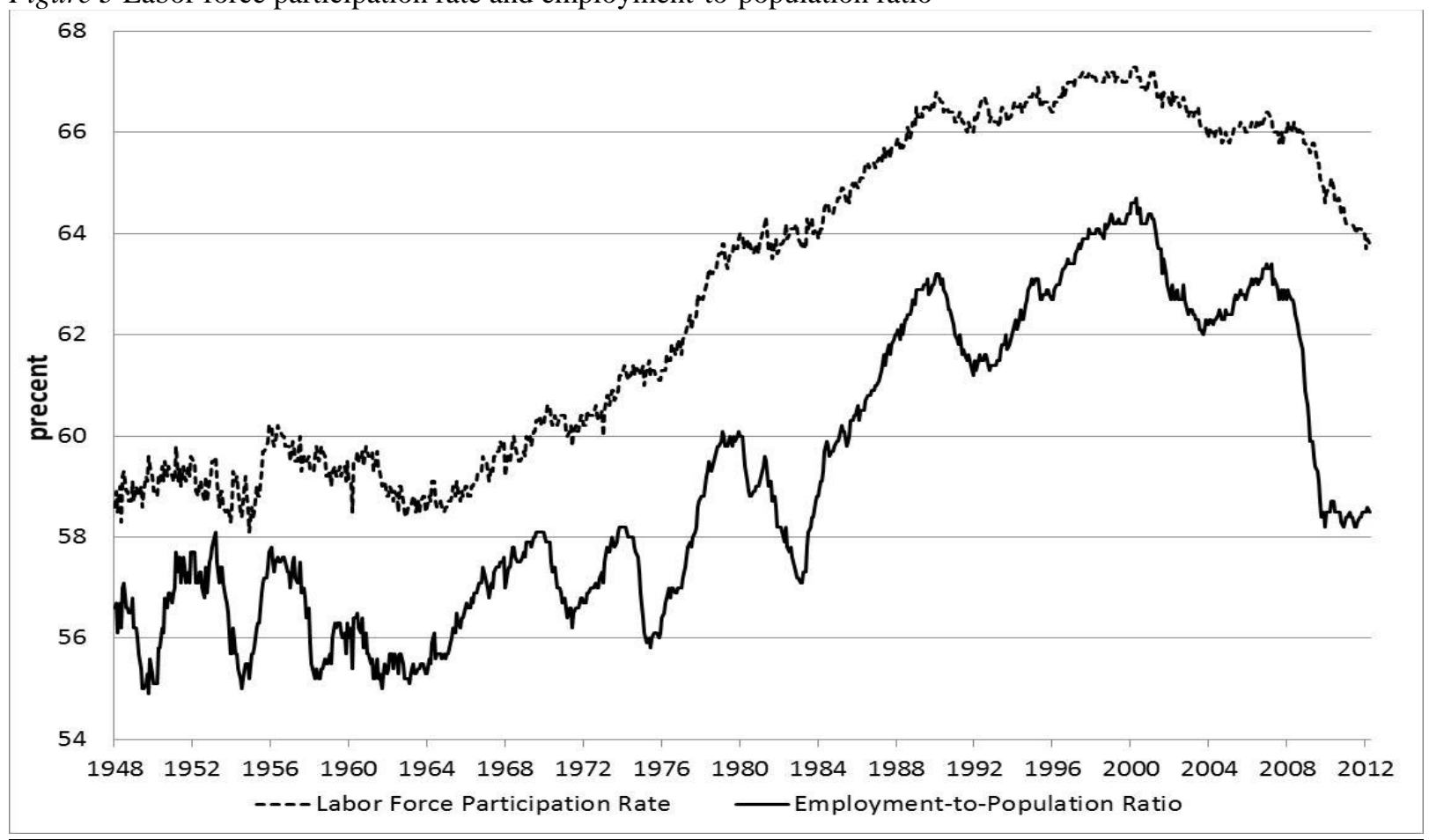

Source: www.bls.gov

Figure 4 Official unemployment rate and broader BLS U-6 measure

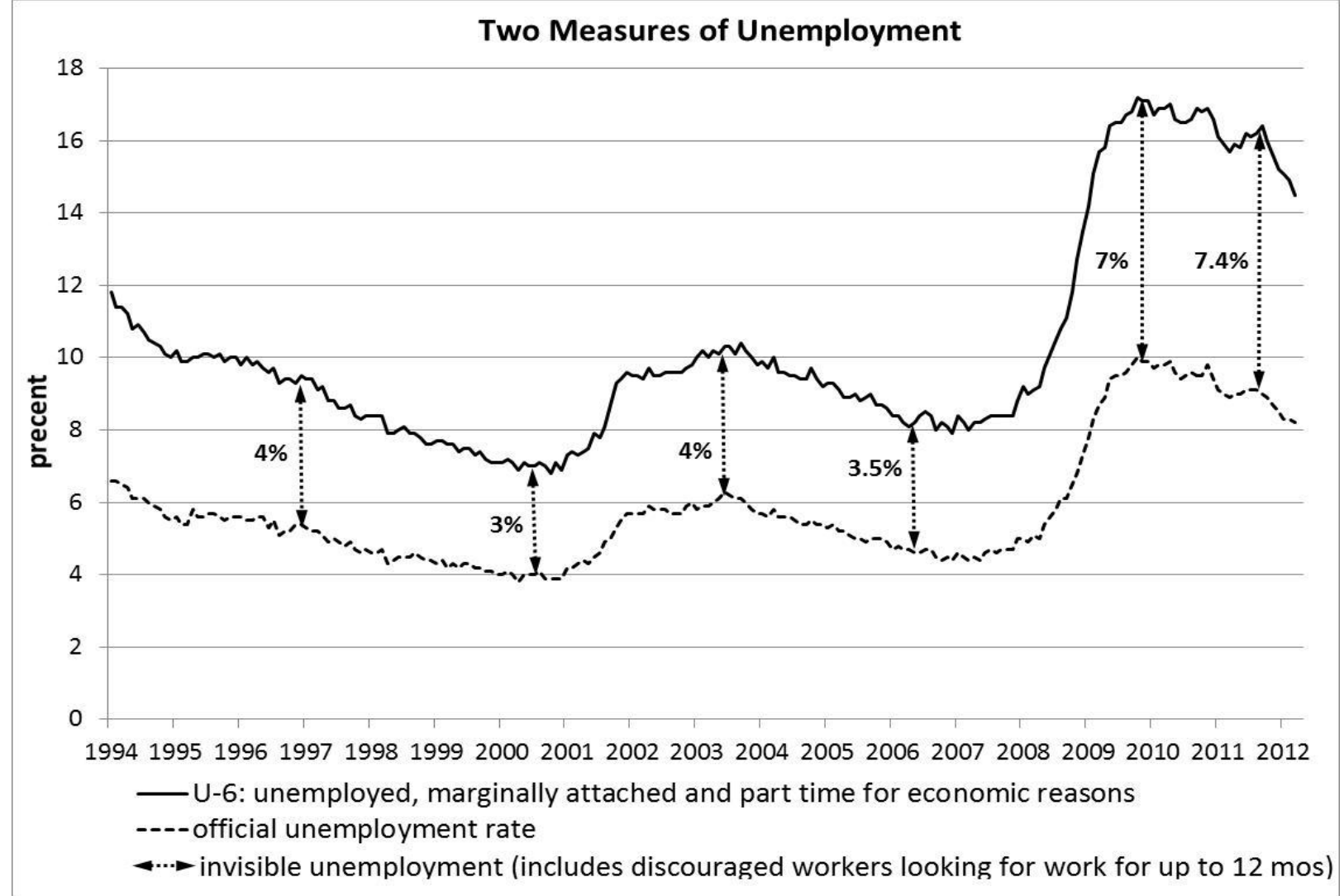

Source: www.bls.gov 
Today we require anywhere between 100,000 to 140,000 jobs per month just to keep up with population growth, ${ }^{4}$ whereas on average the economy has been adding 130,000 jobs per month since 2010. Though in early 2012, the pace of job growth has picked up slightly, it will still take more than a decade to bring the unemployment rate down to the desired 5 percent.

How does policy deal with these seemingly intractable developments in the labor market? And is 5 percent unemployment the best that we can do (the 1950s, 1960s and the 1990s had seen unemployment rates between 2.5 percent and 4 percent)? Clearly a comprehensive program for job growth is necessary, but so long as the focus remains on the output gap, rather than the employment gap, there will be no deliberate measures for addressing these specific problems. One such deliberate measure is direct employment - a policy response that has been gradually abandoned in the postwar era and particularly at the time when labor market conditions have deteriorated further and further. Direct job creation has a number of advantages over the pumppriming methods of stabilization: it delivers greater primary and secondary employment effects, it can be designed to deal with structural and regional unemployment problems directly, and it provides a more stable floor to demand than income support programs (for other benefits of the direct approach, see Tcherneva $2011 \mathrm{~b}$ and 2012). If designed in a bottom-up fashion by providing an employment safety net to those who experience the most precarious labor market conditions, it can also help improve the overall income distribution (more below). But direct job creation was a very small part of the stabilization efforts during the latest crisis. It is not surprising then that reducing the unemployment rate is taking so long to achieve.

In light of our focus on the employment gap, rather than the output gap, it can be argued that the countercyclical function of government does not just include an increase in expenditures at a time when private spending collapses, but also involves an increase in public sector employment, at a time when private firms are slashing jobs - thereby dampening the unemployment effect. The challenge is designing a public employment safety net that offers a genuine countercyclical employment mechanism. Several proposals, such as the employer-oflast-resort and the job guarantee, already exist (e.g., Minsky 1986); a third proposal will be suggested below that uses the social entrepreneurial and nonprofit sectors for that purpose. In the absence of such a countercyclical employment mechanism that makes a job offer at some base

\footnotetext{
${ }^{4}$ These numbers are based on labor force growth projections before and after the crisis that are consistent with demographic trends (Toossi 2012, 2004).
} 
wage to those who are willing and able to work but who cannot find private sector employment, conventional public employment can provide some stabilization. Data indicates that government has performed a similar, though very limited, role during previous recessions. What is notable in the current downturn is that the public sector, as a whole, has had a mixed impact. While federal government hiring increased during the recession, offsetting some of the massive losses in private nonfarm employment, state and local employment was rapidly decelerating, becoming negative in mid-2009. Furthermore, since mid-2011, all public sectors have been shedding jobs, thereby imparting a significant drag on this very fragile employment recovery (Figure 5).

Figure 5 Public employment trends since the start of the Great Recession

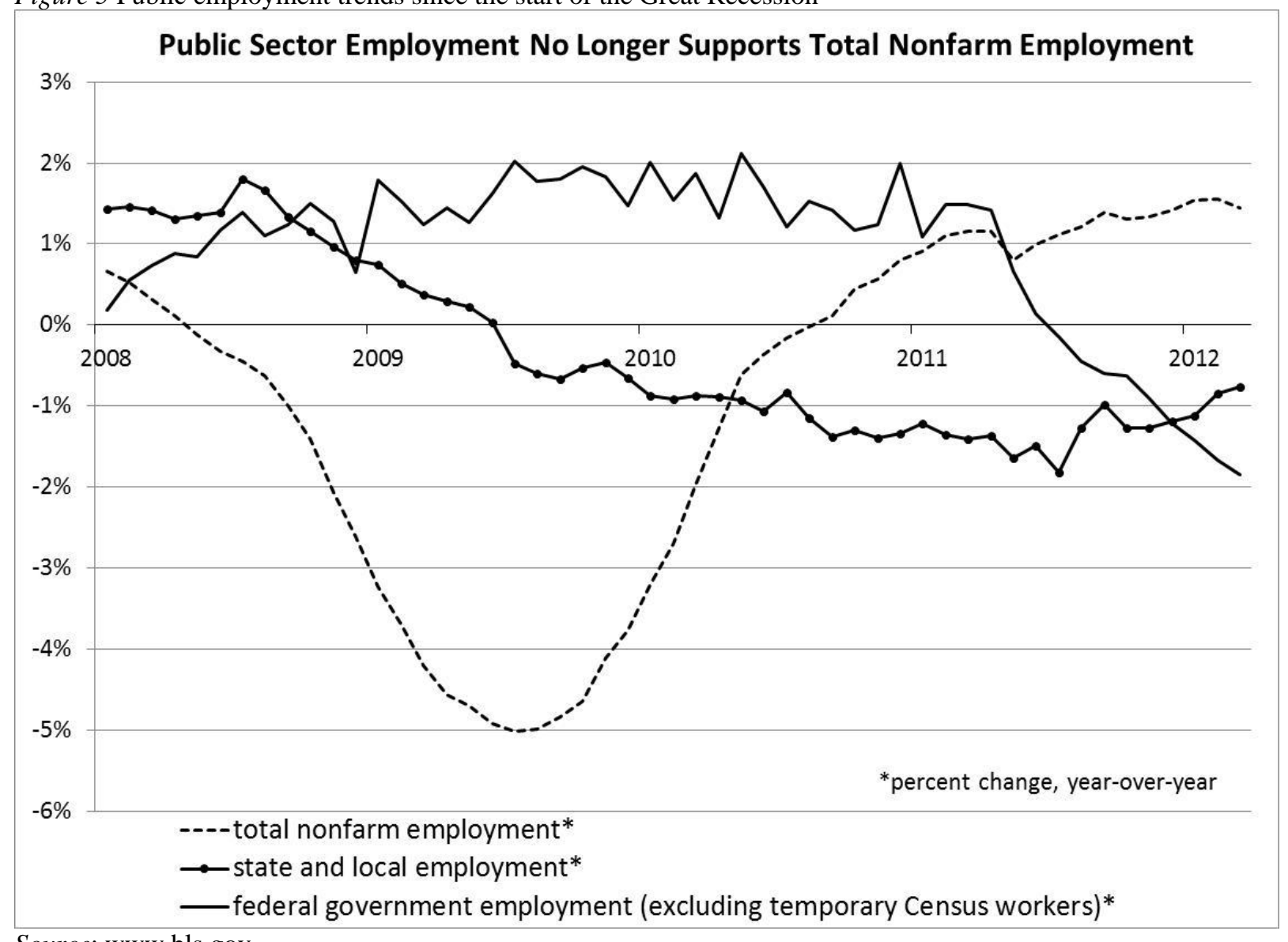

Source: www.bls.gov

Closing the employment gap today means creating more than 20 million jobs, and direct public employment is part of the solution. A safety net for those with the greatest difficulty in reentering the private job market can be designed to offer a transitional job in the public or nonprofit sectors. As income and employment for the most vulnerable is stabilized, demand 
would trickle up throughout the economy, generating a multiplier effect from this type of direct employment that would produce an indirect and induced effect in the private sector sufficient to bring the overall unemployment levels down to desired levels. By contrast, the Recovery Act included a wide range of government expenditures which had a rather small direct job creation component relative to needs. Furthermore, a large number of the jobs created offered employment for the relatively highly skilled and educated workers. Thus, it was not just the size of the stimulus that was small, but it was also how it was targeted that bears responsibility for the dismal job creation effects.

\section{Job Growth and the Recovery Act}

The Recovery Act aimed to save or create 3 to 4 million jobs (Romer and Bernstein 2009). Considering the long-term unemployment trends discussed above and the swift deterioration in the employment situation prior to the passage of the Act and during its early days of implementation, this job creation objective was woefully inadequate (total nonfarm employment in 2008 alone fell by 3.6 million and by another 5 million in 2009).

At the end of fiscal year 2009, the Government Accountability Office estimated the initial job impact of the Recovery Act (GAO 2009). The distribution of funds during the first few quarters after the passage of the Recovery Act reflected the overall fund distribution over the life of the stimulus package - about a third went to tax relief, another third went to mandatory programs like entitlements where funding was disbursed by legally required payments formulas, and the final third was allocated to discretionary spending programs that were funded through grants, contracts, and loans. The first two components (taxes and entitlements) have no direct employment effect and a minimal indirect employment effect. Their induced employment effect would depend on the proportion of tax rebates and other income support that would go toward the purchases of real goods and services rather than toward the servicing of debts. The induced effect from such countercyclical stabilizing policies tends to put a floor on aggregate demand and job losses, but it does not produce net new job growth. By contrast, discretionary spending by government in the form of contracts to firms, grants to states and nonprofits, and loans is the place to look for more significant direct, indirect, and induced job creation effects.

A review of the funding initiatives indicates that this component was not only small, but also poorly targeted. For example, 33 percent of total ARRA spending (i.e., \$265 billion) went 
toward grants, contracts, and loans, and was spread over the course of a little over four years. During fiscal year 2009, that amounted to $\$ 47$ billion dollars in discretionary spending (GAO 2009). The number of jobs saved or created with these funds, as reported by the recipients of recovery funding, equaled 640,329 - two thirds of which were in education. Some of these jobs included teachers, librarians, principals, and support staff in institutions of higher education. An examination of the government databases with recipient reports indicates that most of these jobs were saved jobs, and tough government methodology and reporting difficulties do not permit a clear separation between new jobs created and jobs retained. Additionally, the jobs in education also included financial aid to students in the form of work-study programs. Work study "jobs" are neither new jobs created, nor old jobs retained-work study programs offer financial aid to students by allowing them to perform clerical tasks, grading, and some research assistance to faculty. Indeed students are properly considered to be outside of the labor force and are therefore not counted in the conventional measures of unemployment. Thus, the direct job creation impact from spending on education - the largest component in the Recovery Act's "grants, contracts, and loans" category - is overestimated by the full-time-equivalent working hours performed by students as part of their financial aid package.

The direct job creation efforts in education unfortunately had a small impact on the unemployment rates in that industry (those efforts included the actual teaching and administrative jobs that were saved or created with recovery funding). BLS data shows that unemployment in education grew very rapidly in 2007 and 2008 and then flattened during 20092012 (www.bls.gov). While joblessness in the education industry has stopped growing, it has not begun to decline. This is largely because the funding was both too small and poorly directed. ${ }^{5}$ First, while it was able to save some jobs, many school districts across the country continued slashing their payrolls. Second, a large amount of the funding through the department of education did not go towards direct job creation or retention, but went to higher education institutions for the purposes of providing student grants and loans, training and education initiatives, cost of living adjustments, and other-needed initiatives, but with low employmentcreation effects.

Similarly, funding allocated to transportation, infrastructure, energy, weatherization, and housing also had a small direct employment effect. And due to the same reporting and

\footnotetext{
${ }^{5}$ Spending on education totaled $\$ 90$ billion over the course of four years (www.recovery.gov).
} 
methodological reasons, it is difficult to parse out how many of these were new and how many were retained jobs. While some funding was associated with new hiring, many projects involved equipment purchases, maintenance, and other operations that did not create any new jobs. Additionally, a large amount of R\&D funding went to universities and hospitals for the purposes of medical research. In many instances, jobs were created for highly skilled and/or highly paid workers - from funding project managers and supervisors to supporting research laboratories, faculty, and graduate assistants. To be sure, the Recovery Act underwrote many important projects and initiatives, but it did not have the needed job creation effect because it did not explicitly put the unemployed to work. Only in a relatively small percentage of cases did it support jobs that were in imminent danger of being slashed, like those of teachers and law enforcement officers.

The Council of Economic Advisors, the Congressional Budget Office, and a few other macroeconomic models have estimated the annual job impact from the total expenditures in the Recovery Act (i.e., from spending on tax rebates, entitlements, grants, loans, and contracts) and their respective multiplier effects. The estimates range from 250,000 in 2009 to between 2.4 million and 3.6 million in 2010 (CEA 2011) to between 1.6 million and 4.6 million in 2011 (CBO 2011b). Again, the estimates include the direct, indirect, and induced job creation effects based on a range of estimated multipliers. This is the gross job creation from the Recovery Act, not the net job growth during that period. In 2009, for example, the economy in the aggregate was shedding jobs (5.06 million to be exact), while in 2010 and 2012 nonfarm payrolls grew by 1.03 million and 1.8 million respectively. In other words, these numbers would have been far worse without the stimulus package. By the end of 2011, 78 percent of total ARRA funding (\$840 billion) was spent (cbo.gov and recovery.gov), which suggests that the cost-per-job from the Recovery Act spending was roughly between $\$ 80,000$ and \$164,000. Again, the jobs that were directly created or saved by the government grants, contracts, and loans were a very small proportion of the overall job effect and they tended to be high skill, high education, high paying jobs, therefore mitigating the "bang for the buck" from the Recovery Act. Thus, these new jobs helped the segment of the labor market that tends to experience more stable employment conditions in recessions and expansions. On the other hand, the component of the Recovery Act that aimed to deal explicitly with the employment challenges faced by the most vulnerable members of society - the elderly, low-skill, and unemployable workers - allocated a paltry $\$ 4.5$ 
billion or about half a percent of total stimulus spending. This was the "Job Training and Unemployment" component of the Recovery Act, which included community service employment for older Americans, training and employment programs, special education and rehabilitative services, and other (www.recovery.gov).

\section{RETHINKING COUNTERCYCLICAL GOVERNMENT SPENDING}

In the vast majority of cases, the Recovery Act provided much needed dollars to recipients. Note however, that much of this government spending went towards programs that were traditionally part of normal government operations and were either gradually devolved to the state level (UI, Medicare, TANF) and/or systematically underfunded over the last few decades (e.g., education, infrastructure, research, and development, etc.). In short, the type of discretionary spending that took place under the Recovery Act essentially boosted support for programs that are part of conventional government operations. After all of the recovery funds are exhausted this year, these government operations will be divested of the additional support. Even worse, the overall government budget position is poised to become a major drag on the fragile economic recovery due to looming budget cuts negotiated in 2011. To restate, support for conventional government programs do not and should not constitute countercyclical fiscal policy. They are programs that require continued support as they fulfill important public purpose functions at all phases of the business cycle.

\section{Away from Trickle-Down Keynesianism toward Bottom-Up Fiscal Policy}

So what constitutes countercyclical government spending? Traditionally, the government budget has moved against the cycle due to automatic stabilizers like declining tax revenues and increasing income assistance. Note, however, that there is no component of government budgeting that deals with countercyclical changes in the labor market explicitly. What we have instead is a form of trickle-down Keynesianism, which stresses policies that provide contracts to firms with guaranteed profits, accelerated depreciation schedules, tax incentives, and direct investment subsidies. These policies have been very successful in stabilizing incomes, cash flows and profits to the firm sector (and indeed corporate profits only two years after the greatest financial collapse in postwar history are back to record highs), but they have been very unsuccessful in stabilizing employment, much less in producing or maintaining anything close to 
genuine full employment over the business cycle. The trickle-down mechanism of contemporary fiscal policy works via restoring firm incomes and cash flows first, leaving any increases in employment and household incomes to be secondary effects. Considering the modern compensation formulas for top management, it is no wonder that the improvement in aggregate incomes has gone largely to the top 10 percent (and more specifically to top 1 percent) of the income distribution (Saez 2012), whereas the absence of a solid pro-employment recovery has ensured that incomes of the bottom 90 percent have declined.

There is another way in which the current policy approach represents trickle-down Keynesianism. As reflected in the Recovery Act, contracts to firms, pro-investment policies, and even needed R\&D initiatives tend to improve the employment conditions of those individuals who are high-skill, high-education, and high-pay faster than the employment conditions of those with lower education and skill. The segmentation in the labor market, or more precisely the gap in employment rates between those with higher education relative to those with high school education or less, is preserved not only by the differences in productivity of the two cohorts, but also by the way fiscal policy itself works in a pro-cyclical manner when it comes to employment-i.e., by providing job opportunities to the "employable" rather than creating opportunities for those who face greater challenges in the labor market.

It is therefore important to rethink what it means for the public sector to provide genuine countercyclical stabilization. It is not only a matter of reversing the collapse in profits, output, and firm cash flows, but is also a matter of offsetting the trends in private sector labor markets rather than of mimicking them. In other words, whereas the logic of private sector employment dictates that high-skill, high-education individuals will experience higher levels of private sector employment, it is the logic of the public sector to stabilize employment for those who are left behind. In other words, when a job opportunity is missing for the low-skill, low-education individuals, the task of countercyclical public employment policy is to provide them with one in the public sector - a voluntary opportunity that would allow them to gain valuable on-the-job training and education, while upgrading their skill and experience in order to transition more easily to private sector employment. In short, direct public sector employment is a crucial countercyclical employment safety net that does not rely on dubious secondary and tertiary effects from pump-priming to improve the employment conditions for those at the bottom of the 
income distribution. Direct employment does so in a deliberate manner by putting the jobless to work in projects that serve the public purpose.

\section{Countercyclical Direct Employment through Nonprofits and Social Enterprises}

In the immediate postwar era, public employment and investment were part of traditional crisis resolution policies. Today, direct employment plays a very small part in countercyclical stabilization. Part of the difficulty lies in the reorientation of policy toward greater reliance on trickle-down supply- and demand-side economics and less on more direct initiatives like public works and investment. The other problem is with the general distaste in the US for direct government intervention. So how do we design a countercyclical employment policy that is not necessarily provided through the familiar New Deal public works model, nor managed by the federal or state governments? One way to do this is to run countercyclical employment stabilization through the nonprofit and social entrepreneurial sectors instead. The reason why they are especially suitable for the job is that they tend to operate in a countercyclical fashion themselves, fulfilling needs and offering services to communities during recessions that the public sector has either failed to provide or has simply devolved to the nonprofit sector. The social entrepreneurial sector is crucial because its very reason for existence is to achieve certain social objectives that have not been traditionally resolved by the private market. Though such objectives usually include environmental cleanup, poverty alleviation, and other, it can be argued that the elimination of forced idleness (i.e., involuntary unemployment) is another important social goal that can be addressed by these sectors in conjunction with the other social objectives.

Similar to the way the Recovery Act has allocated funds to states, universities, and private contractors, the federal government can allocate grants to nonprofits and social enterprises with the explicit provision that they hire the unemployed in transitional projects that address some important public functions. Note that nonprofits are organized in an entrepreneurial fashion all the time in order to fill new needs like environmental cleanup, sustainable agriculture, and urban farming; they are better organized, more familiar with local needs and resources, and are always in need of more helping hands. Policy can provide funding in support to these institutions for the purpose of providing employment to those with greatest difficulty reintegrating into the labor market, i.e., the low-skill, low-pay, long-term unemployed individuals. The federally funded grants-based model of the program will mean that the projects 
will be evaluated for effectiveness and performance the way grants and contracts are evaluated today, except the evaluation criteria will include specific socioeconomic measures such as employment creation, environmental impact, public goods provisioning, community development, and physical and human resource creation, renewal, and enhancement. In other words, to design a direct job creation program for the most vulnerable labor market participants, one does not need big government planning or decision-making. The nonprofit market can do the job, so long as it has the resources. What is required of the federal government is to invite the proposals, assess the projects the way it would with any current private sector contract, perform due diligence in reporting and quality control, and allocate the funding for worker wages and materials (and in many cases the funding need not be 100 percent because the nonprofits and social enterprises already have some resources for the purpose). The difference between the nonprofit direct job creation model and conventional fiscal policies is that it is a long-run program that has the explicit objective to deal with the problem of unemployment directly, rather than treat is as a bi-product of growth. Instead of extending contracts to private firms with guaranteed profits that may or may not result in net new employment, this program would fund nonprofits and social enterprises to design projects for the public purpose that are staffed with individuals currently unemployed at a base wage. Nonprofit work is highly countercyclical, which is why it is well suited to providing the automatic stabilization discussed above. As the economy slumps, existing unemployment agencies can be used to provide placement of the jobless into these nonprofit projects. As the economy recovers, the same agencies can provide job placement into higher paying private sector work. There already exists significant infrastructure in the US that can help with the execution of such a program.

Direct employment schemes can be organized and executed in multiple ways - through the communities, nonprofits, social enterprises, and conventional public services and infrastructure investment initiatives. What is required is for the federal budget to include a permanent countercyclical employment stabilization fund, which will expand in recessions as unemployed private sector workers enter transitional public service jobs, and shrink in expansions as the economy recovers and those workers are rehired by the private sector.

This is a bottom-up approach in the truest sense of the phrase-powered by communities, localities, and the individuals themselves. The absence of robust job creation today is not only due to inadequate and misdirected government spending, but also to the notable absence of direct 
employment initiatives from the stabilization tools of the policy maker. Once fiscal policy is reoriented to target the labor demand gap rather than the output gap, growth becomes a byproduct of a strong pro-employment policy. Finally, for policy to offer a genuine countercyclical stabilization mechanism, the automatic stabilizers must include not only tax and income support policies, but also a countercyclical employment mechanism that deals with those segments of the labor market that experience the most precarious employment conditions. Such countercyclical employment policies would serve as much stronger stabilizers for overall aggregate demand than traditional income support policies. Finally, by making direct employment a permanent feature of countercyclical fiscal policy, the income distribution itself will improve because of faster improvements in the employment and income conditions of those at the bottom of the income ladder.

\section{CONCLUSION}

\section{Debunking the "New Normal" with the New Approach to Fiscal Policy}

The current approach to macroeconomic stabilization can be summed up as "take care of growth, and employment will take care of itself" - a proposition that has become increasingly dubious and has prompted economists to proclaim that the "new normal" of economic growth is consistent with jobless recoveries. This new normal today includes a NAIRU of 6.7 percent (Weidner and Williams 2011; Daly et al. 2011). The approach proposed here is to make direct job creation a salient feature of fiscal policy, where the objective of the government is to close not the output gap but the labor demand gap. This can be done by establishing a different kind of safety net for the most vulnerable labor market participants that offers a job at a base wage in a community project that serves the public purpose. Such an approach can be summed up as "take care of employment, and growth will take care of itself." Indeed jobless growth and jobless recoveries lose their meaning under this approach. Fiscal policy will no longer work through the two flawed trickle-down mechanisms: the first, which works at the aggregate level by restoring aggregate profits but failing to deliver robust improvements in overall employment conditions; and the second, which works at a more disaggregated level in labor markets and improves the relatively stronger employment conditions of the highly skilled, high-pay workers first, without requisite improvements for workers who experience more precarious labor force attachment, high unemployment rates, and greater volatility in unemployment. With such reorientation of 
fiscal policy, the new normal of 6.7 percent NAIRU becomes unfounded, but so does the conventional NAIRU of 5 percent. The NAIRU is essentially a rhetorical device adopted by economic profession to sidestep a problem that it has failed to solve through priming the pump. When employment reductions are produced by direct employment at the bottom, rather than by priming the pump in an inflationary manner, the level of unemployment that can be achieved before inflationary tendencies are observed would be far lower than the currently accepted "full employment" rate of 5 percent. In the absence of such an orientation to fiscal policy, conventional aggregate demand management policies will keep eroding the income distribution while failing to reduce unemployment aggressively enough or make any meaningful improvements in the disturbing labor market trends outlined above.

These days, when so many countries are focused on budget cuts and austerity, it may seem odd to regard aggressive expansionary fiscal policy as a member in good standing of the "status quo." It is, however, the only other fiscal policy option that garners any serious (albeit waning) attention from policymakers. In the absence of a critical reflection on these two policy approaches, the Great Recession will leave us with the wrong lessons learned - namely that the economy is entering a new normal, where little if anything can be done about the problem of unemployment. What is required instead is a rethinking of fiscal policy altogether and a refocusing of the policy response toward closing the labor demand gap by designing novel countercyclical stabilization mechanisms that offset fluctuations in private labor markets. 


\section{REFERENCES}

Arnold, R. 2009. “The Challenges of Estimating Potential Output in Real Time.” Federal Reserve Bank of St. Louis Review 91(4): 271-90.

Bernanke, B.S. 2000. “Japanese Monetary Policy: A Case of Self-Induced Paralysis?” In R. Mikitani and A. Posen (eds.), Japan's Financial Crisis and its Parallels to U.S. Experience. Washington, DC: Institute for International Economics.

Berglund, P.G. 2006. "Paradox of Thrift and Budget in a Simple Keynesian Growth Model." In Berglund P. G. and Vernengo, M. (eds.), The Means to Prosperity: Fiscal Policy Reconsidered. New York, NY: Routledge: 149-201.

Congressional Budget Office (CBO). 2011a. Historical and Projected Estimates of Potential GDP and the NAIRU (January), http://www.cbo.gov/taxonomy/term/281/all?page=4, accessed April 1, 2012.

Congressional Budget Office (CBO). 2011b. Estimated Impact of the American Recovery and Reinvestment Act on Employment and Economic Output from January 2011 through March 2011 (May), http://www.cbo.gov/sites/default/files/cbofiles/ftpdocs/121xx/doc12185/05-25-arra.pdf, accessed April 1, 2012.

Council of Economic Advisors (CEA). 2011. The Economic Impact of the American Recovery and Reinvestment Act of 2009 (July), http://www.whitehouse.gov/sites/default/files/cea_7th_arra_report.pdf, accessed April 1, 2012.

Daly, M., B. Hobijn, A. Sahin, and R. Valletta. 2011. "A Rising Natural Rate of Unemployment: Transitory or Permanent.” Working Paper 2011-05. San Francisco, CA: Federal Reserve Bank of San Francisco.

Government Accountability Office (GAO). 2009. "Recovery Act: Recipient Reported Jobs Data Provide Some Insight into Use of Recovery Act Funding, But Data Quality and Reporting Issues Need Attention." Report to Congress GAO-10-223, November: 1-69. 
Keynes, J.M. 1964[1936]. The General Theory of Employment, Interest, and Money. New York: Harcourt-Brace \& World, Inc.

-1980. Activities 1940-46. Shaping the Post-War World: Employment and Commodities. Volume XXVII of Collected Works, D. Moggridge (ed.). London, UK: Macmillan.

Lucas, R.E., Jr. 1980. “The Death of Keynesian Economics.” Issues and Ideas. University of Chicago, Chicago, IL. Winter: 18-19.

Mayer, Gerald. 2010. "The Trends in Long Term Unemployment and Characteristics of Workers Unemployed for More than 99 Weeks." Congressional Research Service Report 75700/R41559, http://www.fas.org/sgp/crs/misc/R41559.pdf

Minsky, H.P. 1986. Stabilizing an Unstable Economy. New Haven, CT: Yale University Press.

Okun, A. 1962. "Potential Output: Its Measurement and Significance." In Proceedings of the Business and Economic Statistics Section, American Statistical Society. Washington, D.C.: American Statistical Association.

Reinhart, C.M. and K. Rogoff. 2009. This Time is Different: Eight Hundred Centuries of Financial Folly. Princeton: Princeton University Press.

Romer, C. and J. Bernstein. 2009. "The Job Impact of the American Recovery and Reinvestment Plan.” January 10. http://otrans.3cdn.net/45593e8ecbd339d074_13m6bt1te.pdf

Saez, E. 2012. "Striking It Richer: The Evolution of Top Incomes in the United States." Stanford Center for the Study of Poverty and Inequality (updated with 2009 and 2010 estimates). Original methodology outlined in Saez, E. and Picketty, T. 2003. "Income Inequality in the United States, 1913-1998." Quarterly Journal of Economics, 118(1): 1-39.

Tcherneva, P. 2012. “On-the-Spot Employment: Keynes's Approach to Full Employment and Economic Transformation." Review of Social Economy 70(1): 57-80.

_ 2011a. "Bernanke's Paradox: Can He Reconcile His Position on the Federal Budget with His Charge to Fight Deflation?" Journal of Post Keynesian Economics 33(3): 411433. 
_ 2011b. "The Case for Labor Demand Targeting." Journal of Economic Issues 45(2): 401-410.

Toossi, M. 2004. "Labor Force Projections to 2012: The Graying of the US Workforce." Monthly Labor Review. Bureau of Labor Statistics, (January): 37-57.

— 2012. "Labor Force Projections to 2020: A More Slowly Growing Workforce." Monthly Labor Review. Bureau of Labor Statistics, (January): 43-64.

Weidner, J. and J.C. Williams. 2011. "What Is the New Normal Unemployment Rate?" Federal Reserve Bank of San Francisco Economic Letter 2011-05, (February): 1-6.

Wiedemer, K. 2011. “How Many 99ers Are Really Out There?” Denver Unemployment Examiner, January 30. 